\title{
De regionale corona-aanpak internationaal vergeleken
}

\author{
Sofie Dreef, Caspar van den Berg \& Annelien Zaal*
}

\section{$1 \quad$ Inleiding}

Al ruim een jaar lang houdt Covid-19 de wereld in zijn greep. Hoewel er met de ontwikkeling van werkende vaccins licht gloort aan het einde van de tunnel, is die tunnel tegelijkertijd nog lang. Sinds het uitbreken van de pandemie hebben overheden wereldwijd met drastische maatregelen geïntervenieerd om de verspreiding van het virus in te dammen. Dergelijke maatregelen zullen ook de komende tijd nodig en van kracht blijven. Toch zijn er grote verschillen tussen landen in de snelheid, het type en de ingrijpendheid van de Covid-maatregelen.

De afgelopen maanden zijn diverse wetenschappelijke studies gepubliceerd die deze verschillen in aanpak tussen landen in kaart brengen en pogen te verklaren. Wat in deze studies echter zelden aan de orde komt, is de regionale dimensie van de Covid-19-pandemie. Mogelijk heeft dat te maken met de traditionele focus op de nationale staat als analyse-eenheid bij internationaal vergelijkend bestuurskundig onderzoek, en zeer waarschijnlijk ook met de beschikbaarheid van data. Toch is dit opvallend, gegeven de aard van de pandemie. Al in de eerste golf werd breed opgemerkt dat het verschil in het aantal besmettingen binnen landen groter is dan het verschil tussen landen (Visser, 2020; Van Uffelen \& Frijters, 2020). Bovendien is niet in alle landen sprake van landelijk geldende maatregelen. Afhankelijk van de staatsvorm en de mate van decentralisatie van taken en bevoegdheden is er meer of minder differentiatie en subnationale autonomie ten aanzien van de aan Covid-19 gerelateerde interventies. Met andere woorden, om verschillen in de bestrijding van de pandemie binnen en tussen landen beter te kunnen begrijpen, moeten we deze analyseren op het niveau van het Bestuurlijk Regionale Ecosysteem - het geheel aan bestuurlijke actoren en samenwerkingsverbanden in een samenhangend geografisch gebied (Van den Berg, Dreef \& Clemens, 2021).

Uit de constatering dat de verschillen waarin het coronavirus zich binnen landen manifesteert groter zijn dan de verschillen waarmee het zich tussen landen manifesteert, vloeien interessante nieuwe vragen voor vergelijkend bestuurskundig onderzoek voort. In deze bijdrage aan het dossier onderzoeken we op basis van beschikbare data en bestaande studies de variatie in de aanpak van Covid-19 tus-

* Sofie Dreef MSc LLM schrijft haar proefschrift over bestuurlijk regionale ecosystemen aan de Rijksuniversiteit Groningen/Campus Fryslân en werkt als adviseur openbaar bestuur bij Berenschot. Prof. dr. Caspar van den Berg is hoogleraar global and local governance aan de Rijksuniversiteit Groningen/Campus Fryslân. Annelien Zaal MA is afgestudeerd in internationale betrekkingen aan de Universiteit Utrecht. Zij volgt momenteel een master international law aan de Vrije Universiteit. 
Tabel 1 Aantal Covid-19 besmettingen per land, periode 1 tot 30 april 2020

\begin{tabular}{lrrrrr}
\hline Land & $\begin{array}{c}\text { Aantal besmettingen } \\
\text { I april 2020 } \\
\text { Totaal }\end{array}$ & $\begin{array}{c}\text { Per 100.000 } \\
\text { inwoners }\end{array}$ & $\begin{array}{c}\text { Aantal besmettingen } \\
\text { 30 april 2020 } \\
\text { Totaal }\end{array}$ & $\begin{array}{c}\text { Per 100.000 } \\
\text { inwoners }\end{array}$ & $\begin{array}{c}\text { Verschil aantal } \\
\text { besmettingen } \\
\text { Procentueel }\end{array}$ \\
\hline Duitsland & 77.872 & 95 & 163.009 & 198 & $209,3 \% \uparrow$ \\
Frankrijk & 56.362 & 84 & 167.326 & 250 & $296,9 \% \uparrow$ \\
Italië & 110.574 & 184 & 205.463 & $34 \mid$ & $185,8 \% \uparrow$ \\
Nederland & 13.614 & 78 & 39.316 & 225 & $288,8 \% \uparrow$ \\
Verenigd Koninkrijk & 43.398 & 66 & 177.543 & 270 & $409,1 \% \uparrow$ \\
\hline
\end{tabular}

sen en binnen landen, en destilleren uit de verschillende onderzoeken de belangrijkste verklarende variabelen voor de variatie tussen én binnen landen. Daarbij richten we ons in het bijzonder op het door Hendriks (2020) ontwikkelde analysekader voor de vergelijking van Covid-maatregelen op landenniveau in WestEuropa, bestaande uit de interacterende pijlers nationale cultuur en nationale staatstraditie (samen het 'institutionele filter'). Voor ons roept dit de vraag op in hoeverre het institutionele filter ook op subnationaal niveau mede verklarend is voor de variatie in Covid-maatregelen. Immers, cultuur en politiek-bestuurlijke traditie kunnen binnen een land aanmerkelijk van elkaar verschillen.

Deze hypothese verkennen we in deze bijdrage. Daarbij richten wij ons op - de subnationale bestuurlijke eenheden in - een aantal West-Europese landen, te weten Duitsland, Frankrijk, Italië, Nederland en het Verenigd Koninkrijk. In het bijzonder van belang is dat de verdeling van taken en bevoegdheden over de overheidslagen in deze landen op een andere manier is geregeld. Anders gezegd, subnationale overheden hebben in het ene land meer eigen zeggenschap over het Covid-19-beleid dan in het andere. Daarnaast kiezen we voor een focus op de eerste periode van de pandemie, van maart tot en met mei 2020. Dit om gebruik te kunnen maken van bestaande data over het aantal Covid-19-besmettingen op regionaal niveau, verzameld door Visser (2020) voor de maand april. Een dergelijke inventarisatie per regio is voor de periode daarna - van relatieve ontspanning in de zomer, tot een tweede golf in het najaar van 2020 - (nog) niet openbaar beschikbaar. Bovendien richten de tot nu toe gepubliceerde wetenschappelijke onderzoeken naar verklaringen voor landelijke verschillen in de aanpak van Covid-19 zich met name op deze eerste periode.

Uit onze bijdrage volgt een onderzoeksagenda om subnationale verschillen in aanpak binnen Europese landen te verklaren.

\section{De verspreiding van Covid-19 in april 2020: Verschillen binnen landen zijn groter dan verschillen tussen landen}

De Oxford Covid-19 Government Response Tracker (OxCGRT) monitort het aantal Covid-19-besmettingen per land. Voor april 2020 geeft dit het in tabel 1 weergegeven beeld. 
Tabel 2 Regio's met het minste en meeste aantal Covid-19-besmettingen per land, periode 1 tot 30 april 2020

\begin{tabular}{|c|c|c|c|c|c|c|}
\hline & \multicolumn{2}{|c|}{$\begin{array}{l}\text { Regionale besmet- } \\
\text { tingen per } 100.000 \\
\text { inwoners op } \\
\text { I april } 2020\end{array}$} & \multicolumn{2}{|c|}{$\begin{array}{l}\text { Regionale besmet- } \\
\text { tingen per } 100.000 \\
\text { inwoners op } \\
30 \text { april } 2020\end{array}$} & \multicolumn{2}{|c|}{$\begin{array}{c}\text { Regionale stijging } \\
\text { van besmettingen } \\
\text { per } 100.000 \\
\text { inwoners in de } \\
\text { maand april }\end{array}$} \\
\hline & $\begin{array}{l}\text { Kleinste } \\
\text { aantal }\end{array}$ & $\begin{array}{l}\text { Grootste } \\
\text { aantal }\end{array}$ & $\begin{array}{l}\text { Kleinste } \\
\text { aantal }\end{array}$ & $\begin{array}{l}\text { Grootste } \\
\text { aantal }\end{array}$ & $\begin{array}{l}\text { Kleinste } \\
\% \text { stijging }\end{array}$ & $\begin{array}{l}\text { Grootste } \\
\% \text { stijging }\end{array}$ \\
\hline Duitsland & $\begin{array}{l}\text { Mecklen- } \\
\text { burg-Vor- } \\
\text { pommern } \\
(25,2)\end{array}$ & $\begin{array}{l}\text { Beieren } \\
(126,2)\end{array}$ & $\begin{array}{l}\text { Mecklen- } \\
\text { burg-Vor- } \\
\text { pommern } \\
(42,9)\end{array}$ & $\begin{array}{l}\text { Beieren } \\
(321,8)\end{array}$ & $\begin{array}{l}\text { Mecklen- } \\
\text { burg-Vor- } \\
\text { pommern } \\
(170,2 \%)\end{array}$ & $\begin{array}{l}\text { Branden- } \\
\text { burg } \\
(327,4 \%)\end{array}$ \\
\hline Frankrijk & $\begin{array}{l}\text { Pays de la } \\
\text { Loire }(9,8)\end{array}$ & $\begin{array}{l}\text { Île-de- } \\
\text { France } \\
(99,5)\end{array}$ & $\begin{array}{l}\text { Nouvelle- } \\
\text { Aquitaine } \\
\text { (40) }\end{array}$ & $\begin{array}{l}\text { Île-de- } \\
\text { France } \\
(283,2)\end{array}$ & $\begin{array}{l}\text { Corsica } \\
(118,1 \%)\end{array}$ & $\begin{array}{l}\text { Hauts-de- } \\
\text { France } \\
(643,5 \%)\end{array}$ \\
\hline Italië & $\begin{array}{l}\text { Molise } \\
(160)\end{array}$ & $\begin{array}{l}\text { Valle } \\
\text { d'Aosta } \\
(502,4)\end{array}$ & $\begin{array}{l}\text { Molise } \\
(298)\end{array}$ & $\begin{array}{l}\text { Valle } \\
\text { d'Aosta } \\
\text { (989) }\end{array}$ & $\begin{array}{l}\text { Umbria } \\
(127,2 \%)\end{array}$ & $\begin{array}{l}\text { Trentino } \\
\text { Alto Adige } \\
(354,8 \%)\end{array}$ \\
\hline Nederland & $\begin{array}{l}\text { Fryslân } \\
(22,2)\end{array}$ & $\begin{array}{l}\text { Noord- } \\
\text { Brabant } \\
(138,9)\end{array}$ & $\begin{array}{l}\text { Fryslân } \\
(80,9)\end{array}$ & $\begin{array}{l}\text { Noord- } \\
\text { Brabant } \\
(3 \mid 8,4)\end{array}$ & $\begin{array}{l}\text { Groningen } \\
(200,3 \%)\end{array}$ & $\begin{array}{l}\text { Flevoland } \\
(381,9 \%)\end{array}$ \\
\hline Verenigd Koninkrijk & $\begin{array}{l}\text { Noord- } \\
\text { lerland } \\
(5,4)\end{array}$ & $\begin{array}{l}\text { Londen } \\
(122,9)\end{array}$ & $\begin{array}{l}\text { South } \\
\text { West } \\
(110,3)\end{array}$ & $\begin{array}{l}\text { Wales } \\
(306,8)\end{array}$ & $\begin{array}{l}\text { Londen } \\
(222 \%)\end{array}$ & $\begin{array}{l}\text { Noord- } \\
\text { lerland } \\
(3.450 \%)\end{array}$ \\
\hline
\end{tabular}

Zowel begin als eind april was het aantal besmettingen per 100.000 inwoners op nationaal niveau het grootst in Italië. De relatieve toename van het aantal besmettingen was in Italië echter het kleinst. In Nederland en Frankrijk lag de relatieve toename van het aantal besmettingen dicht bij elkaar; in het Verenigd Koninkrijk was de toename relatief gezien het grootst.

Als we voor dezelfde periode kijken naar de toename van het aantal besmettingen op regionaal niveau, zien we in alle vijf de landen een grote spreiding. In tabel 2 zijn data per land opgenomen voor (1) de regio's met het kleinste en grootste aantal besmettingen per 100.000 inwoners op 1 april 2020; (2) de regio's met het kleinste en grootste aantal besmettingen per 100.000 inwoners op 30 april 2020; en (3) de regio's met de kleinste en grootste procentuele stijging van het aantal besmettingen per 100.000 inwoners in de maand april.

De data laten zien dat er sprake is van een grote diversiteit binnen landen als het gaat om de verspreiding van Covid-19. Dat is ook logisch: een hoger aggregatieniveau middelt plaatselijke hotspots en geeft een minder extreem beeld dan een lager aggregatieniveau. Maar het betekent ook dat om inzicht te krijgen in de verspreiding van het virus, kijken naar het nationale niveau minder veelzeggend is dan kijken naar het subnationale niveau. In sommige regio's had het virus in 
Tabel 3 Overall government response index per land, periode 1 tot 30 april 2020

\begin{tabular}{lllll}
\hline Land & $\begin{array}{l}\text { Aantal } \\
\text { besmettingen, } \\
\text { procentuele } \\
\text { toename }\end{array}$ & $\begin{array}{l}\text { Overall } \\
\text { government } \\
\text { response } \\
\text { I april 2020 }\end{array}$ & $\begin{array}{l}\text { Overall } \\
\text { government } \\
\text { response } \\
\mathbf{3 0} \text { april 2020 }\end{array}$ & $\begin{array}{l}\text { Overall } \\
\text { government } \\
\text { response, } \\
\text { verschil }\end{array}$ \\
\hline Duitsland & $209,3 \% \uparrow$ & 61,67 & 67,78 & +6, II \\
Frankrijk & $296,9 \% \uparrow$ & 72,50 & 73,33 & $+0,83$ \\
Italië & $185,8 \% \uparrow$ & 72,78 & 79,72 & $+6,94$ \\
Nederland & $288,8 \% \uparrow$ & 65,00 & 65,00 & 0 \\
Verenigd Koninkrijk & $409,1 \% \uparrow$ & 63,33 & 64,17 & $+0,84$ \\
\hline
\end{tabular}

april nog nauwelijks toegeslagen; andere regio's werden des te zwaarder getroffen. Regio's als Beieren (Duitsland), Noord-Brabant (Nederland) en Wales (Verenigd Koninkrijk) lagen qua aantal besmettingen veel dichter bij elkaar dan bij sommige andere regio's in hun eigen land.

Bij het analyseren van de overheidsmaatregelen en mogelijke verklaringen voor de variatie hierin is het dus van belang om deze regionale variatie van het aantal Covid-19-besmettingen in de analyse mee te nemen en niet louter naar het nationale niveau te kijken. Dit is echter wel de standaard: internationaal-vergelijkend onderzoek bestaat in overweldigende mate uit vergelijkingen tussen de instituties en het beleid op nationaal-niveau (Lijphart, 1971; Heady, 2001; Pollitt \& Bouckaert, 2017).

\section{De aanpak van Covid-19: verschillen tussen én binnen landen}

De Oxford Covid-19 Government Response Tracker monitort tevens de door overheden genomen maatregelen voor negentien verschillende indicatoren, verdeeld over vier clusters: beperkingen en lockdowns, economie, zorgstelsel en diversen. De 'overall government response index' geeft inzicht in de overheidsrespons op alle vier de clusters. De 'stringency' index' geeft inzicht in de strengheid van de coronamaatregelen en is gebaseerd op alle indicatoren in het cluster 'beperkingen en sluiting'1 en op één indicator in het cluster 'gezondheidszorgsystemen'2.

Tabel 3 geeft voor de vijf onderzochte landen het volgende weer:

- de procentuele toename van het aantal besmettingen in de maand april 2020;

- de OxCGRT overall government response index op 1 april 2020;

- de OxCGRT overall government response index op 30 april 2020;

- het verschil in de overall government response index tussen 1 en 30 april 2020.

Uit deze data blijkt dat de overheden die in de periode 1 tot 30 april 2020 procentueel de kleinste toename zagen in het aantal besmettingen, Italië en Duitsland, 
de maatregelen het meeste opschroefden. Overheden die met procentueel (veel) grotere toenamen van het aantal besmettingen te kampen hadden - het Verenigd Koninkrijk (een ruime verviervoudiging), Frankrijk en Nederland -, namen weinig tot geen extra maatregelen.

De mate waarin regionale differentiatie in de aanpak van Covid-19 in theorie mogelijk is, verschilt voor de vijf casuslanden. De gebiedsdelen van het Verenigd Koninkrijk hebben de grootste bevoegdheden: Noord-Ierland, Schotland en Wales hebben volledige autonomie als het gaat om de aanpak van Covid-19 (Van den Berg, 2011; www.instituteforgovernment.org.uk/). Daarna volgen de Duitse deelstaten (www.bundesregierung.de) en Italiaanse regio's (Cavatorto \& La Spina, 2020; Governo Italiano, Presidenza del Consiglio dei Ministri 2021a en 2021b). In Nederland en Frankrijk wordt centraal beleid gevoerd, waarbinnen decentrale overheden aanvullende maatregelen kunnen nemen. Deze ruimte is in Nederland iets groter dan in Frankrijk (Muller, Kummeling \& Nehmelman, 2020; Van den Berg, 2011).

Ook de mate waarin subnationale overheden in de praktijk gebruikmaken van de ruimte die zij hebben om eigen Covid-19-beleid te voeren, verschilt. De Oxford Covid-19 Government Response Tracker bevat slechts voor enkele landen data over de genomen maatregelen op regionaal niveau. Van onze vijf casuslanden geldt dat alleen voor het Verenigd Koninkrijk. Gegevens over de genomen maatregelen op regionaal niveau zijn ook elders niet centraal beschikbaar. Voor een analyse van de regionale variatie in het gevoerde Covid-19-beleid zal handmatige, systematische dataverzameling dan ook noodzakelijk zijn. Hier illustreren we aan de hand van enkele voorbeelden op welke wijze maatregelen op regionaal niveau in de praktijk vorm kregen.

In Duitsland is sprake van een lappendeken van maatregelen die deels landelijk gelden en deels enkel in een specifieke deelstaat van kracht zijn. Zo voerde deelstaat Beieren tijdens de eerste golf strengere maatregelen in dan de andere deelstaten, bijvoorbeeld door het verschuiven van de datum van de eindexamens (Süddeutsche Zeitung, 2020) en het afzeggen van de grote vakbeurs Internationale Handwerksmesse (Der Spiegel, 2020). Ook op dit moment verschillen de maatregelen per deelstaat: zo past deelstaat Baden-Württemberg de zogenaamde '15 kilometer regel'3 niet toe (www.baden-wuerttemberg.de).

De aanpak van de epidemie in Frankrijk is in hoge mate gecentraliseerd, maar speelt wel in op de regionale situatie. Op basis van een aantal criteria (zoals het aantal besmettingen en de ziekenhuiscapaciteit) is een stoplichtmodel ontwikkeld dat bepalend is voor de geldende maatregelen in een specifiek gebied. Afhankelijk van de kleur van het gebied kan de prefect aanvullende maatregelen nemen, zoals het verplicht stellen van het dragen van een mondkapje buiten of het sluiten van wegen.

In Italië uitten de verschillen in regionale aanpak zich onder andere in het beleid voor testen en bron- en contactonderzoek. Twee van de drie zwaarst getroffen regio's, Veneto en Emilia Romagna, kozen voor een proactieve strategie (zoals testen bij milde en asymptomatische gevallen en het proactief opsporen van mogelijke besmettingen), terwijl Lombardije een meer conservatieve aanpak koos: per 
hoofd van de bevolking werden in Lombardije de helft minder testen afgenomen dan in Veneto en Emilia Romagna (Berardi e.a., 2020, 459).

In Nederland verschilde de mate waarin regionale differentiatie binnen de landelijk geldende regelgeving mogelijk was per periode. Van den Berg e.a. (2021) ontwaren tussen maart en november 2020 een golfbeweging, die zij indelen in vijf fases (zie figuur 1).

Van 13 maart tot 1 december vonden landelijk genomen besluiten hun basis in regionale regelgeving. De juridisch bindende voorschriften van het ministerie van Volksgezondheid, Welzijn en Sport en het ministerie van Justitie en Veiligheid werden regionaal vastgesteld door de voorzitters van de veiligheidsregio's in de vorm van noodverordeningen. De voorzitters hadden de bevoegdheid om, binnen de juridisch bindende voorschriften, aanvullend regionale maatregelen te treffen. Over het algemeen is hier weinig gebruik van gemaakt. Waar dit wel gebeurde, ging het om procedurele kwesties (zoals de benoeming van handhavers) en werd de afwijking vaak met andere regio's afgestemd. De mate waarin veiligheidsregio's van hun bevoegdheid gebruik hebben gemaakt, verschilt aanzienlijk: zo heeft veiligheidsregio Limburg-Noord op 41 onderwerpen afgeweken, terwijl Utrecht en Twente dat maar op zes onderwerpen deden (Becker e.a., 2020).

In het Verenigd Koninkrijk, tot slot, voerden Engeland, Schotland en Wales de eerste beperkingen in op 26 maart en Noord-Ierland op 28 maart, met slechts kleine verschillen in hun respectieve benaderingen. Uit regionale data van de Oxford Covid-19 Government Response Tracker is af te leiden dat in de maand april de maatregelen in alle regio's even streng waren. In Noord-Ierland en Schotland nam de algehele overheidsrespons (dat wil zeggen niet alleen beperkingen en lockdowns, maar ook maatregelen gericht op de economie, het zorgstelsel en overige maatregelen) toe in de maand april, in Engeland en Wales niet.

\section{Mogelijke verklaringen voor verschillen tussen landen}

Sinds de uitbraak van de crisis zijn er verschillende onderzoeken uitgevoerd naar mogelijke verklaringen voor verschillen tussen landen in de overheidsaanpak van Covid-19. In deze paragraaf bespreken we een aantal van deze studies, waarbij we stilstaan bij de gekozen sample (landen/periode), de variabelen die zijn onderzocht en de resultaten.

Op basis van een analyse van de timing van drie beleidsmaatregelen (sluiting van scholen, nationale lockdowns en het uitroepen van de noodtoestand), genomen door de overheden van alle EU-lidstaten plus het Verenigd Koninkrijk, Zwitserland, IJsland en Noorwegen in de periode januari-maart 2020, concluderen Toshkov, Yesilkagit en Carroll (2020) dat in landen die hoger scoren als het gaat om effectiviteit van de overheid en gerelateerde variabelen (zoals rule of law en de betrokkenheid van experts in het beleidsproces), de reactiesnelheid van de overheid ten aanzien van het virus lager was. Ook landen die hoog scoren op sociaal vertrouwen (vertrouwen in elkaar en in de overheid) en algemene vrijheden, kennen een tragere overheidsrespons. Voorts bleken de institutionele variabelen 


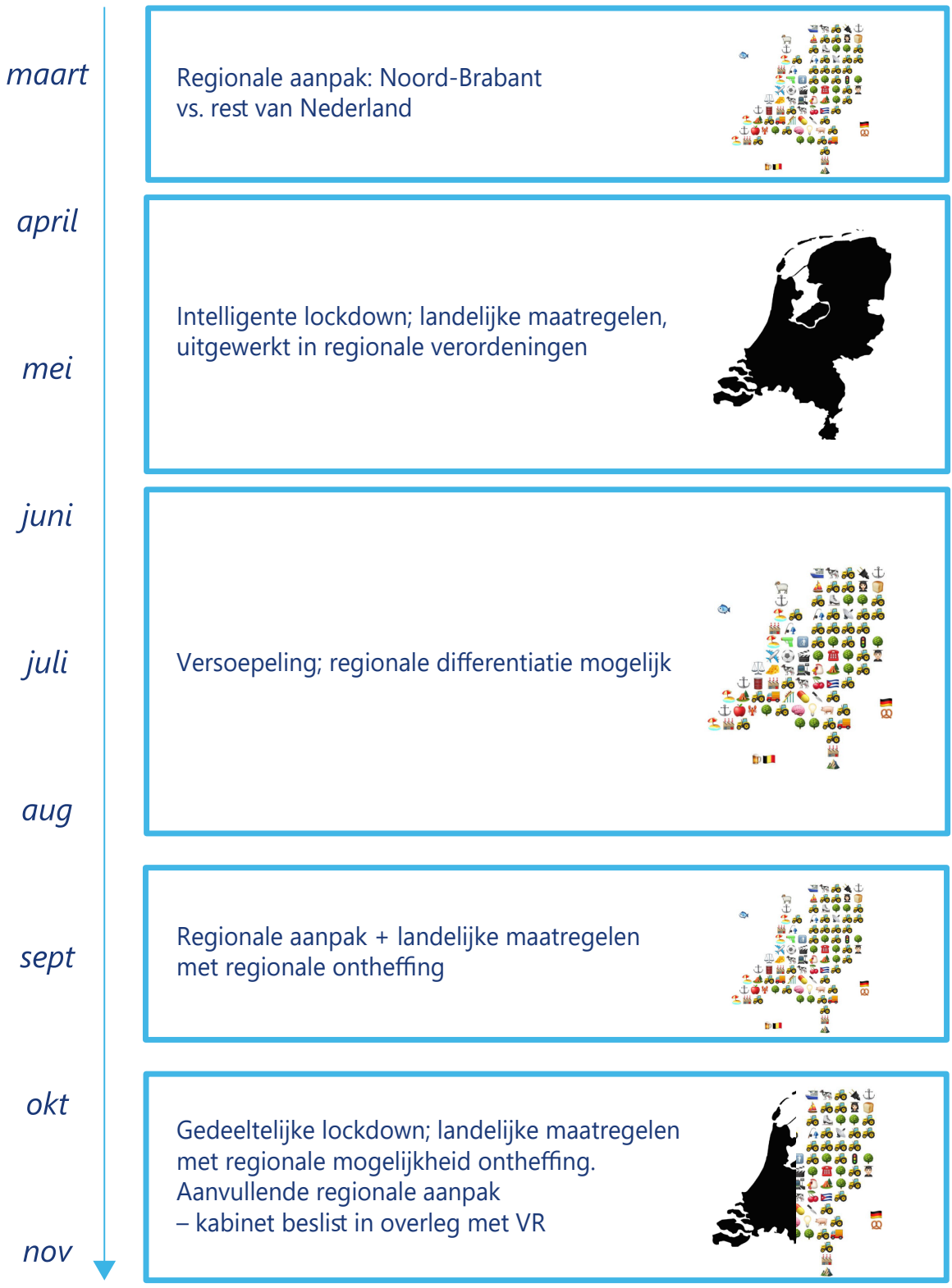

Figuur 1 Nederlandse bestuurlijke aanpak van Covid-19 in een golfbeweging; de inkleuring van de kaart van Nederland geeft aan of er sprake is van ruimte voor regionale differentiatie: de kaart met emoticons illustreert regionale verschillen, de kaart in het zwart illustreert landelijk beleid (kaart van Nederland in emoticons door Mathieu van Woerkom) 
regionalisme en federalisme een significant negatief verband te houden met de reactiesnelheid. Tot slot speelden politieke verhoudingen niet of nauwelijks een rol in de timing van de maatregelen.

Volgens The Economist (2020) verklaart de mate van vertrouwen (in de overheid en in de maatschappij) de verschillen in overheidsaanpak binnen Europa. Noorden West-Europese landen die relatief hoog scoren op vertrouwen in de overheid namen in het eerste kwartaal van 2020 over het algemeen minder strenge maatregelen dan Oost-Europese landen met een laag sociaal vertrouwen. Ook binnen West-Europa namen landen waar het wantrouwen jegens de overheid groter is, strengere maatregelen dan andere landen.

Hendriks (2020) beargumenteert dat zowel het aantal besmettingen als het sociaal vertrouwen op zichzelf een onvoldoende verklarende factor is voor verschillen in de overheidsaanpak van Covid-19. Hij voegt het institutionele filter toe als doorslaggevend voor de waargenomen verschillen. Dit filter wordt gevormd door twee samenwerkende elementen: nationale cultuur en staatstraditie. Nationale cultuur, zo stelt Hendriks, kan invulling geven aan het causaal mechanisme tussen sociaal vertrouwen en de genomen maatregelen. Hij bestudeert België, Frankrijk, Italië, Nederland, het Verenigd Koninkrijk en Zweden en constateert dat landen die strengere maatregelen troffen - België, Frankrijk en Italië - hoger scoren op de culturele kenmerken onzekerheidsvermijding, machtsafstand en masculiniteit en juist lager op het kenmerk hedonisme dan de andere drie landen. Bovendien kennen België, Frankrijk en Italië een staatstraditie waarin ruimte is voor het opstellen, uitwerken en uitrollen van gedetailleerde regels en strenge instructies richting de samenleving. Voor Nederland, het Verenigd Koninkrijk en Zweden geldt dit niet.

Desson e.a. (2020b) voerden een vergelijkend onderzoek uit naar de epidemiologische situatie en overheidsmaatregelen in Frankrijk, België en Canada in de periode februari-augustus 2020. De onderzoekers concluderen dat de aanpak in de drie landen in grote mate werd gestuurd door de capaciteit van het zorgstelsel, en dat een grotere mate van federalisme samenhangt met meer gefragmenteerde maatregelen en minder coördinatie tussen de verschillende jurisdicties.

Desson e.a. (2020a) vergeleken de effecten van de Covid-aanpak voor Duitsland, Oostenrijk en Zwitserland in de periode februari-juni 2020. Deze landen hebben sterke historische, culturele en economische banden en kennen alle drie een federaal stelsel waarin subnationale eenheden vergaande autonomie hebben. Ook qua epidemiologische situatie in deze periode zijn ze grotendeels vergelijkbaar. Waar Oostenrijk en Zwitserland ervoor kozen om voor de bestrijding van de pandemie bevoegdheden van het decentrale naar het centrale niveau te herbeleggen, behielden de Duitse deelstaten hun autonomie. De auteurs concluderen dat de drie casuslanden in staat zijn geweest om de verspreiding van het virus relatief snel en succesvol tegen te gaan, waardoor een (naar later bleek tijdelijke) terugkeer naar 'het oude normaal' eerder mogelijk was dan in sommige buurlanden. Daarbij merken zij op dat naast directe beleidsmaatregelen niet-repliceerbare factoren, zoals vertrouwen in de overheid, mogelijk hebben bijgedragen aan de effectiviteit van het gevoerde beleid. 
Elgar, Stefaniak en Wohl (2020) onderzochten voor 84 landen in de periode van 22 januari-3 september 2020 de relatie tussen inkomensongelijkheid en sociaal kapitaal (uitgedrukt in sociaal vertrouwen, groepsverbanden, maatschappelijke betrokkenheid en vertrouwen in de overheid) enerzijds, en overlijden als gevolg van Covid-19 anderzijds. Zij concluderen dat overlijden als gevolg van Covid-19 positief gerelateerd is aan inkomensongelijkheid, sociaal vertrouwen en groepsverbanden, en negatief gerelateerd is aan sociaal kapitaal, maatschappelijke betrokkenheid en vertrouwen in de overheid.

Rodríguez-Pose en Burlina (2020) bestudeerden de geografische spreiding van oversterfte als gevolg van Covid-19 in 206 regio's in 23 Europese landen in de periode januari-juni 2020. Zij concluderen dat er sprake is van een grote ongelijkheid tussen regio's: het grootste aandeel van de oversterfte als gevolg van Covid-19 concentreert zich in een klein aantal regio's. Oversterfte hangt samen met onder meer de verbondenheid van regio's, klimaat, luchtverontreiniging, de kwaliteit van het gezondheidssysteem en de infrastructurele ontsluiting via de weg. Bevolkingsdichtheid en de aanwezigheid van agglomeraties zijn van marginale invloed op de oversterfte. Opvallend noemen Rodríguez-Pose en Burlina hun bevindingen ten aanzien van de kwaliteit van overheidsinstituties en sociale cohesie. De meest zwaar getroffen regio's waren die met een combinatie van zwakke formele institutionele kwaliteit en broze informele instellingen. Een weinig effectieve overheid op nationaal niveau is, veel meer dan op regionaal niveau, bepalend voor de oversterfte als gevolg van Covid-19. Regio's in landen met een zwakke nationale overheid waren bovendien minder goed in staat om bewezen effectieve maatregelen in de bestrijding van de pandemie te implementeren en monitoren.

Bovenstaande publicaties zijn samengevat in tabel 4. 


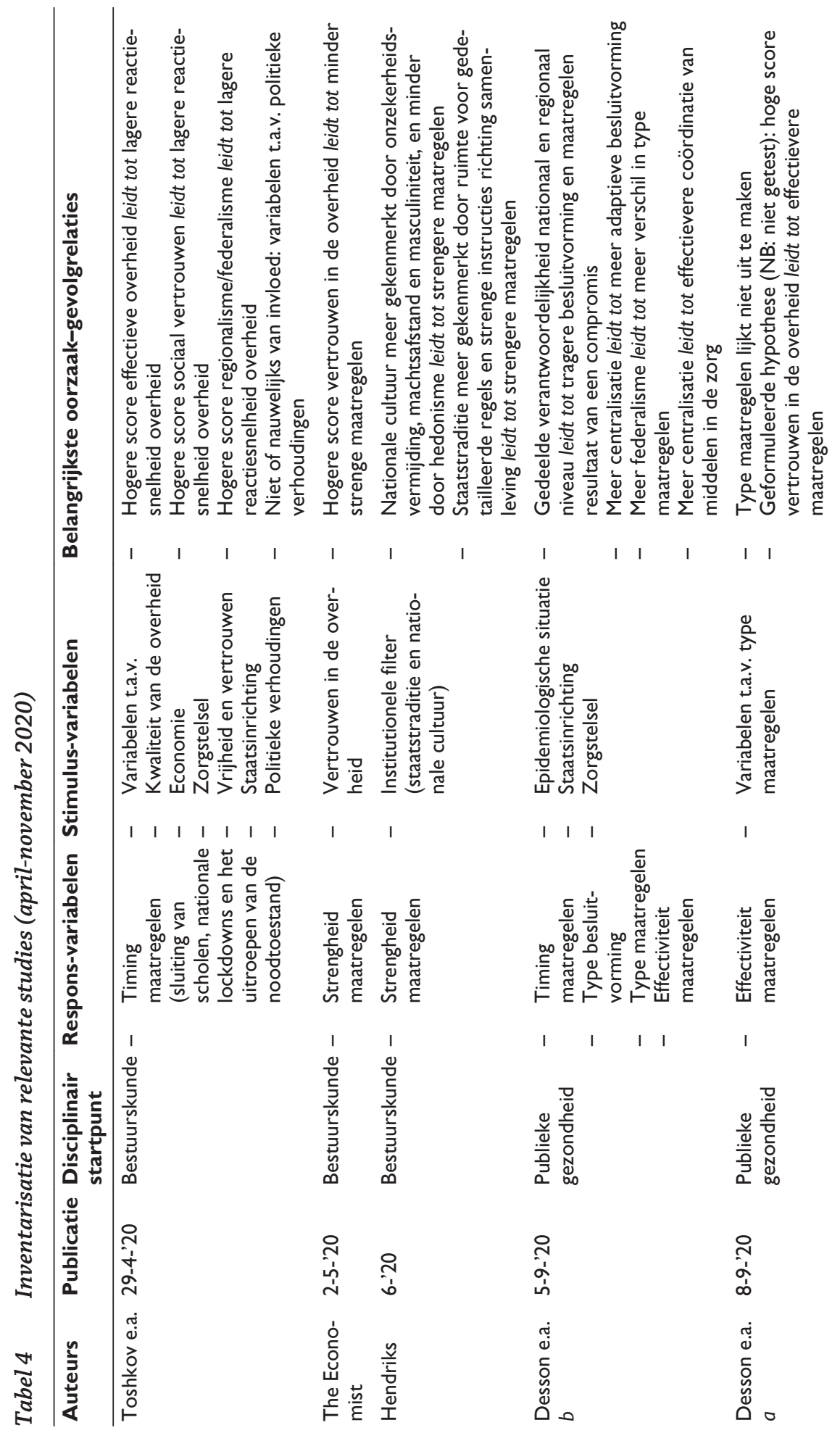


Sofie Dreef, Caspar van den Berg \& Annelien Zaal

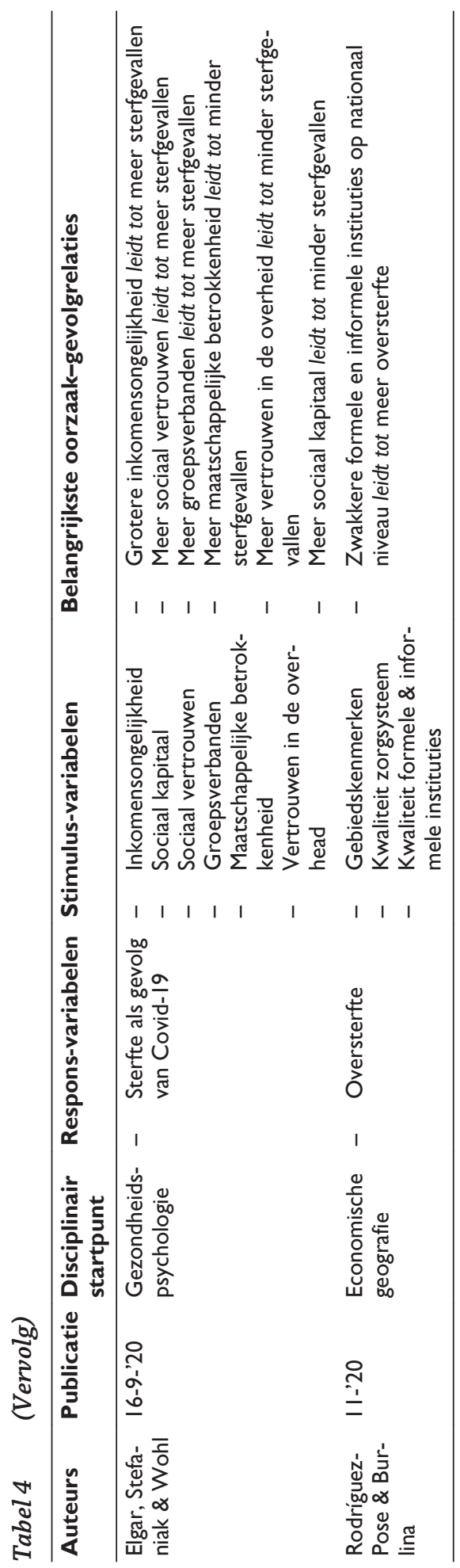




\section{Verschillen in de aanpak van Covid-19 binnen landen verklaard}

Bovengenoemde wetenschappelijke studies roepen de vraag op of de gevonden verklarende variabelen ook relevant zijn voor subnationale verschillen. Dit geldt in het bijzonder voor de kwaliteit van de overheid, sociaal vertrouwen en het institutionele filter. In deze paragraaf doen we een eerste aanzet voor een uitwerking van deze variabelen.

\subsection{Kwaliteit van de overheid}

Verschillende auteurs kijken naar de kwaliteit van de nationale overheid als verklarende variabele voor verschillen in aanpak en impact van Covid-19. De European Quality of Government Index (QoG), die data bevat voor 193 regio's in 23 Europese landen, laat echter zien dat er sprake is van grote verschillen in de kwaliteit van de overheid op subnationaal niveau.

Toshkov e.a. concluderen dat in landen met een effectieve nationale overheid, weinig corruptie en een goed functionerende rechtsstaat de reactiesnelheid van de overheid op de pandemie trager was dan in andere landen. Anderzijds constateren Rodríguez-Pose en Burlina dat landen met zwakke formele instituties te maken hebben met een grotere oversterfte als gevolg van Covid-19. Als verklaring wijzen zij op de tragere, minder heldere en minder adaptieve besluitvorming door deze overheden $(2020,13)$. Bovendien concluderen zij dat de kwaliteit van de nationale overheid veel belangrijker was voor het indammen van het virus dan de kwaliteit van de regionale overheden $(2020,22)$.

De bevindingen van Toshkov e.a. en Rodríguez-Pose en Burlina lijken dus tegengesteld aan elkaar, tenminste als het door Rodríguez-Pose en Burlina veronderstelde mechanisme van tragere besluitvorming inderdaad blijkt te kloppen. Dit vraagt om een aanvullende analyse met behulp van de QoG-regiodata, waarbij zowel de timing van de overheidsmaatregelen als het verloop van de pandemie in ogenschouw wordt genomen.

\subsection{Vertrouwen}

The Economist stelt dat verschillen in strengheid van overheidsmaatregelen worden verklaard door variatie in de mate van vertrouwen in de overheid. Elgar e.a. (2020) concluderen dat vertrouwen in de overheid gerelateerd is aan een lager, en sociaal vertrouwen aan een hoger sterftecijfer als gevolg van Covid-19.

De vraag is of deze variabele ook op subnationaal niveau relevant is. Voor deze analyse kan gebruik worden gemaakt van de European Social Survey (ESS). Deze dataset bevat onder meer de variabele 'vertrouwen in de politiek' (schaal 1-10). De mate waarin er sprake is van regionale verschillen in vertrouwen in de politiek, verschilt per land (zie figuur 2). ${ }^{4}$ Tussen regio's in het Verenigd Koninkrijk is geen significant verschil waarneembaar; hetzelfde geldt voor Frankrijk. In Nederland en Duitsland zijn er wel significante regionale verschillen waarneembaar, maar slechts gering. Zo is er in Nederland alleen een significant verschil in vertrouwen in de politiek tussen de provincie Noord-Holland enerzijds en de provincies Limburg en Zeeland anderzijds. Italië is het land met het grootste aantal significante verschillen tussen regio's. 

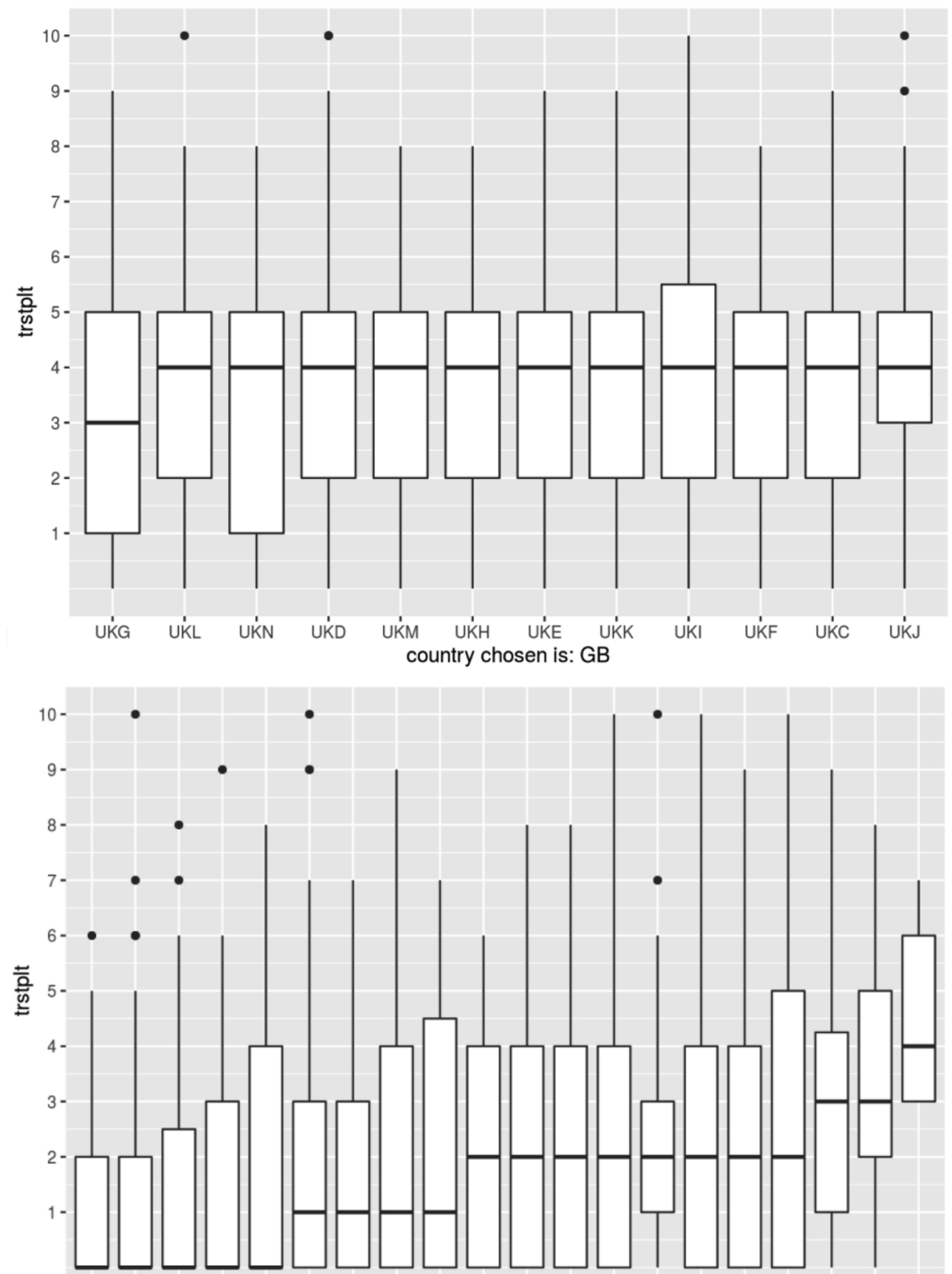

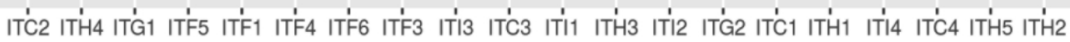
country chosen is: IT

Figuur 2 'Vertrouwen in de politiek' per regio in het Verenigd Koninkrijk (boven) en Italië (onder) (data: European Social Survey (2018)) 


\subsection{Institutionele filter}

Hendriks (2020, 2-3) merkt op dat sociaal vertrouwen een relevante verklarende variabele lijkt voor de West-Europese variatie in de aanpak van Covid-19, maar dat aanvullend onderzoek nodig is naar de mechanismen die ervoor zorgen dat in landen met een lager sociaal vertrouwen vaak sprake is van een strengere lockdown (en vice versa). Hij introduceert hiertoe het begrip 'institutionele filter', bestaande uit twee interacterende factoren: staatstraditie en nationale cultuur.

Er zijn vier dominante West-Europese staatstradities te onderscheiden, die alleen of in combinatie kenmerkend zijn voor een land (zie onder andere Loughlin, Hendriks \& Lindström, 2011). Deze onderscheiding ziet op zowel de interne structuren, arrangementen en verhoudingen binnen de overheid, als op de traditionele verhouding tussen staat en samenleving. Hoewel verschillen in structuren (bevoegdheidsverdeling tussen overheidslagen en mate van decentralisatie) zich enkel op nationaal niveau manifesteren, is er op subnationaal niveau wel degelijk sprake van verschillen in politiek-bestuurlijke en maatschappelijke verhoudingen (zie Keating, 2004).

Vertrekpunt is Hofstedes definitie van cultuur als 'de collectieve mentale programmering die de leden van één groep of categorie mensen onderscheidt van die van andere' (Hofstede, 2011, 3). Cultuur manifesteert zich dus op het niveau van het collectief, maar verschilt van aard, afhankelijk van de definitie van dat collectief. Bijvoorbeeld op basis van sekse, generatie of opleidingsniveau, maar ook op basis van geografie: het dorp, de regio, het land of het werelddeel waar mensen leven (idem). Hofstede, Hofstede en Minkov (2010) onderscheiden zes dimensies waarlangs culturele verschillen kunnen worden waargenomen: (1) machtsafstand, (2) onzekerheidsvermijding, (3) individualisme versus collectivisme, (4) masculiniteit versus femininiteit, (5) lange- versus kortetermijnoriëntatie, en (6) hedonisme versus soberheid.

Hendriks laat zien dat landen met strengere Covid-maatregelen (Frankrijk en Italië) hoger scoren op onzekerheidsvermijding en machtsafstand, en lager op hedonisme. Ook scoren zij, in vergelijking met Nederland (maar niet met het Verenigd Koninkrijk en ook in mindere mate met Duitsland), hoger op masculiniteit. Oftewel: de nationale cultuur van sommige landen werpt minder belemmeringen op voor ingrijpender en strikter beleid dan die van anderen $(2020,11)$.

Het is echter de vraag of de staat het meest aangewezen schaalniveau is om culturele verschillen in kaart te brengen. Lang niet altijd vallen de grenzen van de staat samen met de grenzen van gebieden waar mensen die zich met een bepaalde identiteit vereenzelvigen, leven. In één land wonen vaak meerdere groepen met verschillende identiteiten en culturen, maar deze culturen zijn niet noodzakelijkerwijs gebonden aan de landsgrenzen (Kaasa, Vadi \& Varblane, 2014, 823-824).

In 2014 onderzochten Kaasa e.a. culturele verschillen binnen verschillende 24 Europese landen ${ }^{5}$ op basis van de eerdergenoemde European Social Survey en de European Value Survey. De auteurs focussen vier cultuurdimensies: machtsafstand, onzekerheidsvermijding, individualisme versus collectivisme en masculiniteit versus femininiteit. Hun studie laat een grote diversiteit zien aan regionale culturele variatie onder de onderzochte landen. Voor sommige landen, waaronder Frankrijk en het Verenigd Koninkrijk, geldt dat de variatie tussen subnationale 
culturen groter is dan de variabiliteit tussen nationale culturen (2014, 846-847). Op cultuurdimensies 'machtsafstand' en 'individualisme/collectivisme' is in Duitsland sprake van culturele scheidslijnen tussen oost en west, en noord en zuid (2014, 846). Daarentegen is Nederland cultureel vrij homogeen: de verschillen tussen Nederlandse regio's zijn kleiner dan de verschillen tussen Nederland en andere landen $(2014,839)$.

Deze resultaten laten zien dat het, om een uitspraak te kunnen doen over het institutionele filter als (mede) verklarende factor voor verschillen in aanpak van de Covid-19-crisis, van belang is om niet alleen culturele verschillen tussen, maar ook binnen landen in ogenschouw te nemen.

\section{Conclusie: naar een onderzoeksagenda}

Covid-19 is een wereldwijde pandemie waardoor wij allen getroffen worden. Toch slaat het virus op de ene plek harder toe dan op de andere. Ook reageren overheden anders op het virus, zowel qua snelheid als qua type en strengheid van de maatregelen.

Er is in 2020 uitgebreid onderzoek gedaan naar deze verschillen. In deze bijdrage hebben we een aantal van deze studies op een rij gezet. Zij concentreren zich vrijwel allemaal op het nationale niveau en zoeken naar verklaringen voor verschillen in (de effectiviteit van) de aanpak tussen landen. Wij stellen dat er juist ook binnen landen grote verschillen waarneembaar zijn. Verschillen in de epidemiologische situatie - het aantal besmettingen, ziekenhuisopnames en overlijdensgevallen en in (de effectiviteit van) de gekozen aanpak.

In de meeste landen bestaan significante regionale verschillen ten aanzien van kwaliteit van de overheid, sociaal vertrouwen en het institutioneel filter. Onze verkenning maakt aannemelijk dat deze mede verklarend zijn voor de variatie in Covid-maatregelen tussen subnationale bestuurlijke eenheden. Meer onderzoek is nodig naar de werking van het binnenlandse 'institutionele filter'. Te toetsen hypothesen zijn onder meer:

- Naarmate effectiviteit van de regionale overheid hoger is, neemt de kans op een hogere reactiesnelheid door de overheid op regionaal niveau toe.

- Naarmate de kwaliteit van de overheid in een regio lager is, neemt de kans op meer oversterfte als gevolg van Covid-19 toe.

- Naarmate het vertrouwen in de overheid op regionaal niveau lager is, neemt de kans op strengere regionale Covid-19 maatregelen toe.

- Naarmate het vertrouwen in de overheid op regionaal niveau hoger is, neemt de kans op meer overlijdensgevallen als gevolg van Covid-19 af.

- Naarmate het sociaal vertrouwen op regionaal niveau lager is, neemt de kans op meer overlijdensgevallen als gevolg van Covid-19 af.

- Naarmate regio's hoger scoren op de cultuurdimensies onzekerheidsmijding, machtsafstand en masculiniteit, en lager op hedonisme, neemt de kans op strengere regionale Covid-19-maatregelen toe 
Systematische dataverzameling op het juiste aggregatieniveau zal hierbij een uitdaging vormen, zowel als het gaat om de Covid-19-cijfers (in deze paper maken wij dankbaar gebruik van de door Jelmer Visser verzamelde regionale data voor april 2020) als om de genomen maatregelen op subnationaal niveau.

\section{Noten}

1 Sluiting van scholen, sluiting van werkplekken, verbieden van publieke evenementen, restricties op bijeenkomsten, sluiten van het openbaar vervoer, maatregelen ten aanzien van thuis blijven, restricties op binnenlandse reizen en restricties op internationale reizen.

2 Communicatiecampagnes door de overheid.

3 In de zogenaamde 'corona-hotspots' mogen inwoners niet verder dan 15 kilometer buiten hun woonplaats komen.

4 We zijn dr. Ofer Engel (RUG/Campus Fryslân) erkentelijk voor het maken van de figuur.

5 Italië maakt geen onderdeel uit van de geselecteerde casuslanden.

\section{Literatuur}

Baden-Württemberg. Website overheid: www.baden-wuerttemberg.de/de/service/aktuelleinfos-zu-corona/aktuelle-corona-verordnung-des-landes-baden-wuerttemberg/.

Becker, R., Honée, L., Boogaard, G., \& Geertjes, G.J. (2020). Mate van juridische differentiatie door veiligheidsregio's. https://coronapapers.nl/nieuws-1/nieuws/mate-vanjuridische-differentiatie-door-veiligheidsregio-s .

Berardi, C., Antonini, M., Genie, M.G., Cotugno, G., Lanteri, A., Melia, A., Paolucci, F. (2020). The COVID-19 pandemic in Italy: Policy and technology impact on health and non-health outcomes. Health Policy and Technology, 9 (4): 454-487.

Berg, C.F. van den (2011). Transforming for Europe: The reshaping of national bureaucracies in a system of multi-level governance. Leiden: Leiden University Press.

Berg, C.F. van den, Dreef, S., \& Clemens, S. (2021). Regionaal bestuur tijdens de coronacrisis. https://coronapapers.nl/nieuws-1/nieuws/regionaal-bestuur-tijdens-de-coronacrisis .

Cavatorto, S., \& La Spina, A. (2020). The Politics of Public Administration Reform in Italy. Springer.

Der Spiegel (2020, 2 maart). Internationale Handwerkmesse Wegen Coronavirus Abgesagt. Der Spiegel. www.spiegel.de/wirtschaft/service/internationale-handwerksmessewegen-coronavirus-abgesagt-a-0b54e06d-236b-4e91-8c38-2df35703822f.

Desson, Z., Lambertz, L., Peters, J.W., Falkenbach, M., \& Kauer, L. (2020a). Europe's Covid-19 outliers: German, Austrian and Swiss policy responses during the early stages of the 2020 pandemic. Health Policy and Technology, 9: 405-418.

Desson, Z., Weller, E., McMeekin, P. \& Ammi, M. (2020b). An analysis of the policy responses to the COVID-19 pandemic in France, Belgium, and Canada. Health Policy and Technology, 9: 430-446.

Duitsland. Website overheid: www.bundesregierung.de/breg-de/aktuelles/epidemie-bundkompetenzen-1733634. 
Elgar, F.J., Stefaniak, A., \& Wohl, M.J. (2020). The trouble with trust: Time-series analysis of social capital, income inequality, and COVID-19 deaths in 84 countries. Social Science \& Medicine, 263: 1-6.

European Social Survey (2018). www.europeansocialsurvey.org/.

Governo Italiano, Presidenza del Consiglio dei Ministri (2021a). Coronavirus, le misure adottate dal Governo. www.governo.it/it/coronavirus-misure-del-governo.

Governo Italiano, Presidenza del Consiglio dei Ministri (2021b). Fag sulle misure fino al 10 gennaio 2021. www.governo.it/it/faq-natale.

Hale, T., Boby, T., Angrist, N., Cameron-Blake, E., Hallas, L., Kira, B., ... Webster, S. (2020). Variation in Government Responses to COVID19, Version 9.0 (Working paper). Blavatnik School of Government. www.bsg.ox.ac.uk/covidtracker.

Hale, T., Boby, T., Angrist, N., Cameron-Blake, E., Hallas, L., Kira, B., ... Webster, S. (2020). Oxford COVID-19 Government Response Tracker. Blavatnik School of Government. www.bsg.ox.ac.uk/covidtracker.

Heady, F. (2001). Public Administration, A Comparative Perspective . CRC Press.

Hendriks, F. (2020). De corona-uitbraak en het institutionele filter: Naar een verklaring van West-Europese variaties in beleid. Bestuurswetenschappen, 74 (4): 64-78.

Hofstede, G. (2011). Dimensionalizing Cultures: The Hofstede Model in Context. Online Readings in Psychology and Culture, Unit 2.

Hofstede, G., Hofstede, G.J., \& Minkov, M. (2010). Cultures and Organizations: Software of the Mind. New York: McGraw-Hill.

Kaasa, A., Vadi, M., \& Varblane, U. (2014). Regional Cultural Differences Within European Countries: Evidence from Multi-Country Surveys. Management International Review, 54: 825-852.

Keating, M. (red.) (2004). Regions and regionalism in Europe . Edward Elgar Publishing.

Lijphart, A. (1971). Comparative politics and the comparative method. American Political Science Review, 65 (3): 682-693.

Loughlin, J., Hendriks, F., \& Lidström, A. (red.) (2011). The Oxford Handbook of Local and Regional Democracy in Europe. Oxford University Press.

Muller, E., Kummeling, H., \& Nehmelman, R. (red.) (2020). Instituten van de Staat: staatsrechtelijke en bestuurskundige schets van het openbaar bestuur in Nederland. Deventer: Wolters Kluwer.

Oxford Covid-19 Government response tracker. University of Oxford and Blavatnik School of Government. https://covidtracker.bsg.ox.ac.uk/stringency-scatter.

Pollitt, C., \& Bouckaert, G. (2017). Public management reform: A comparative analysis - into the age of austerity. Oxford University Press.

Rodríguez-Pose, A. \& Burlina, C. (2020). Institutions and the uneven geography of the first wave of the COVID-19 pandemic. Papers in Evolutionary Economic Geography \#20.51.

Süddeutsche Zeitung (2020, 18 maart). Bayern verschiebt das Abitur um drei Wochen. Süddeutsche Zeitung. www.sueddeutsche.de/bayern/coronavirus-bayern-abiturverschoben-1.4849538.

The Economist (2020, 2 mei). Do low-trust societies do better in a pandemic? The Economist. www.economist.com/europe/2020/05/02/do-low-trust-societies-do-better-in-apandemic.

Toshkov, D., Yesilkagit, K., \& Carroll, B. (2020). Government Capacity, Societal Trust or Party Preferences? What Accounts for the Variety of National Policy Responses to the COVID-19 Pandemic in Europe?https://doi.org/10.31219/osf.io/7chpu.

Uffelen, X. van, \& Frijters, S. (2020, 8 mei). Grote verschillen tussen regio's Europa: coronavirus treft Stockholm, Londen, Brussel en Madrid zwaar. De Volkskrant. 
www.volkskrant.nl/nieuws-achtergrond/grote-verschillen-tussen-regio-s-europacoronavirus-treft-stockholm-londen-brussel-en-madrid-zwaar bd5efb6f/ .

Visser, J. (2020). De corona-pandemie in kaart gebracht op subnationaal Europees niveau. Innovation Origins. 